JAS: Jurnal Ilmiah Ahwal Syakhshiyyah

Volume 1 Nomor 2 Tahun 2019

e-ISSN: $2714-7398$

\title{
FILOSOFIS KEWAJIBAN NAFKAH ANAK DALAM UUP ISLAM INDONESIA
}

\author{
Nurhadi ${ }^{1}$, Alfian Qodri Azizi ${ }^{2}$ \\ ${ }^{1}$ Sekolah Tinggi Agama Islam (STAI) Al-Azhar Pekanbaru Riau \\ ${ }^{2}$ Program Pasca Sarjana UIN Sunan Kalijaga \\ e-mail: 1alhadijurnal@gmail.com; 2Vian azizi@yahoo.com
}

Diterima: 25-07-2019 | Direvisi: 22 Novemper 2019 | Disetujui: 12 Desember 2019

(C) 2019 Program Studi Ahwal Syakhshiyyah Fakultas Agama Islam Universitas Islam Malang

\begin{abstract}
Abstrak
Anak umumnya yang menjadi korban dari perceraian kedua orang tuanya. Problem pemberian nafkah anak juga menghantui pasca perkara perceraian diputuskan oleh pengadilan dan menjatuhkan hukuman bagi mantan suami untuk tetap memberikan nafkah anak setiap bulannya sampai anak tersebut dewasa atau mandiri. bagaimanakah ketentuan hukum kewajiban nafkah anak menurut UUP Islam Indonesia dan nilai filosofisnya. Penelitian menggunakan pendekatan ranah kualitatif. Penelitian ini sifatnya lebih ke arah metode kajian atas gagasan konseptual dengan data-data yang dikumpulkan dan yang akan dianalisis bertumpu pada ketersediaan sumber data di perpustakaan (Library Research). Kewajiban menafkahi anak diprioritaskan seorang ayah, namun apabila tidak mampu, maka ibu ikut memikulnya. Usia mendapatkan nafkah mulai 0 hingga 21 tahun atau menikah. Jika seorang PNS maka gaji nafkah anak sebesar 1/3. Filosofi kewajiban nafkah anak dalam UUP Islam, jika ditinjau dari aspek aksiologi kemanfaatan hukum, maka nafkah kepada anak merupakan medium untuk mencapai kesejahteraan masyarakat, dengan terpenuhinya nafkah anak berarti telah mempersiapkan sumber daya manusia yang berkualitas di masa depan, sebab di dalam nafkah anak terkandung tiga aspek pemenuhan kebutuhan dasar (basic need) anak, yaitu kebutuhan primer, kebutuhan rohani (psikis) anak dan kebutuhan intelektual anak. Jika dari segi aksiologi tentang keadilan sebuah hukum, kewajiban nafkah anak memiliki nilai-nilai keadilan yang sangat teologis, keadilan yang sosial dan gender. Sedangkan dari aspek aksiologi kepastian hukum, adanya sanksi hukum pada aturan perundang-undangan hukum keluarga berfungsi sebagai kontrol sosial sebagai upaya preventif untuk mencegah terjadinya tindak penelantaran nafkah anak dan upaya represif (memaksa) orang tua untuk menafkahi anak dengan membayarnya di kemudian hari, hal sebagai jaminan akan Hak Asasi Anak (HAM anak).
\end{abstract}

Kata Kunci: Filosofis, Kewajiban, Nafkah Anak, UUP.

This work is licensed under Creative Commons Attribution Non Commercial 4.0 International License Available online on: http://riset.unisma.ac.id/index.php/fai/index 


\begin{abstract}
Children generally are victims of divorce from both parents. The problem of providing child support also haunts after the divorce case was decided by the court and sentenced the ex-husband to continue to provide for the child every month until the child is an adult or independent. how is the legal provisions of the obligation to support children according to the Indonesian Islamic Law and its philosophical value. Research uses a qualitative realm approach. This research is more towards the method of study of conceptual ideas with data collected and to be analyzed based on the availability of data sources in the library (Library Research). The obligation to provide for a child is prioritized by a father, but if he is unable, then the mother shares it. The age of earning a living from 0 to 21 years or married. If a civil servant then the child living salary is $1 / 3$. Philosophy of the livelihood of children in the Islamic UUP, if viewed from the aological aspect of the benefits of the law, then living for children is a medium to achieve community welfare, with the fulfillment of the child's living means to have prepared quality human resources in the future, because in the lives of children there are three aspects of meeting the basic needs (basic needs) of children, namely primary needs, spiritual (psychological) needs of children and intellectual needs of children. If in terms of axiology about the justice of a law, the livelihood obligations of children have values that are very theological justice, social justice and gender. Meanwhile, from the axiological aspect of legal certainty, the existence of legal sanctions in family law regulations serves as social control as a preventive measure to prevent the occurrence of acts of neglect of children and repressive efforts (forcing) parents to support their children by paying them later, as guarantee of children's rights (children's human rights).
\end{abstract}

Keywords: Philosophical, Obligations, Livelihood of Children, UUP.

\title{
A. Pendahuluan
}

Hubungan suami istri sudah menjadi kodrat akan melahirkan anak, keberadaan anak membawa konsekuensi adanya hak dan kewajiban secara berlawanan antara nak dan orang tuanya. Adanya anak berdampak pada hak-hak tertentu, baik hak material misalnya sandang, pangan dan papan, atau hak inmaterail misalnya ibadah, perhatian, kasih sayang dan interaksi sosial. Nafkah merupakan saah satu diantara hak anak yang harus dipenuhi kedua orang tua. Memenuhi kebutuhan nafkah anak merupakan aplikasi dari tujuan pernikahan dalam mencapai maqashid syariah menjaga keturunan (hifz alnasl) (Mas'ud, 2015: 225). Kebutuhan primer anak seperti sandang, pangan dan papan,

JAS: Volume 1 Nomor 1, 2019 
juga pengobatan dan pendidikan dapat mempengaruhi perkembangan anak secara normal dan baik, agar anak mejadi generasi yang berkopetensi sebagai insane kamil sebagai khalifah di bumi untuk memakmurkanya (Qs al-Baqarah: 30; Azizi, 2016: 1).

Dalam meraih tujuan pernikahan tersebut sangat diperlukan suasana yang kondusif dan stabil dalam lngkungan keluarga, diantara taktiknya memproporsikan tugas dan tanggung jawab kedua oaring tua. Keduanya mempunyai hak andil yang sesuai agar anak tumbuh kembang dengan baik. Dalam Islam hal ini telah di rumuskan, yaitu suami bertanggung jawab menafkahi istri dan anak yang cara yang halal dan baik sesuai kemampuan ekonominya (Al-Subki, 2010: 282), hal ini disindir dalam al-Qur'an surah alBaqarah: 233. Sedangkan istri dituntut untuk mentaati suami, menjaga kehormatan, menjaga rahasia dan juga menjaga harta suami dalam situasi apapun (QS al-Nisa : 34; Nuruddin dan Tarigan, 2016: 206).

Teori Islam ini selanjutnya direalisasikan dalam berbagai hasil regulasi di Negara kita Indonesia, yaitu KHI (Kompilasi Hukum Islam) dan UUP No. 1 th 1974 yang merupakan keberlakukan hukum Islam sebagai legal hukum di Indonesia. Ayat 1 pasal 34 UUP No. 1 th 1974 menyatakan: ayah berkewajiban melindungi istrinya dan memenuhi setiap keperluan hidup dalam rumah tangga tentunya sesuai kemampuannya (Depag RI, 2010: 124). Seorang ayah juga sangat bertanggung jawab terhadap nafkah anaknya, baik dalam pernikahan atau sudah bercerai, sehingga anak tersebut dewasa yaitu berumur 21 tahun (KHI ayat 4 pada pasal 80; Depag RI, 1997/1998: 41 dan 69; KHI dan pasal 41 b UUP 1974; Depag RI, 2010: 125). Tentunya bagi sitri berkewajiban untuk berbuat taat pada suami secara lahir dan batin selama dalam rel syariat Islam, juga mengatur keperluan keluarga dengan sebaiknya ( KHI pasal 83 dan UUP 1974 pasal 34 ayat 2; Depag RI, 1997/1998: 43; Depag RI, 2010: 124).

Peran orang tua dalam menjaga, merawat dan mendidik anak sudah diatur dalam ketentuan tersendiri, agar terjaga keutuhan rumah tangga, namun tidak dapat dipungkiri gejolak dalam kehidupan berumah tangga berakhir dengan perpisahan. Realita perpisahan atau thalak di Negara kita Indonesia dari waktu ke waktu semangkin meningkat yang cukup signifikan, sehingga perlu mendapatkan solusi, karena dampak dari perceraian merupakan hal yang sangat diperhatikan, diantaranya merupakan dampak yang terjadi kepada anak. Anak umumnya yang menjadi korban dari perceraian kedua orang tuanya. Makanya anak yang memiliki hak dari kedua orang tuanya jangan sampai terabaikan, terutama hak nafkah (Muchsin, 2010: 5).

Problem pemberian nafkah anak juga menghantui pasca perkara perceraian diputuskan oleh pengadilan dan menjatuhkan hukuman bagi mantan suami untuk tetap memberikan nafkah anak setiap bulannya sampai anak tersebut dewasa atau mandiri. Berdasarkan hasil penelitian yang dilakukan Stijn Van Huis dari Van Vollen hoven Institute University of Leiden Belanda di PA Cianjur, Jawa Barat 2010, mengungkapkan JAS: Volume 1 Nomor 1, 2019 
problem eksekusi atau pelaksanaan amar putusan sulit untuk ditegakkan apabila mantan suami atau ayah enggan menjalankan amar putusan tersebut dengan suka rela. Padahal banyak istri sudah mati-matian memperjuangkan hak nafkah anaknya di muka pengadilan (Ali/Inu, 2015).

Di sisi lain, salah satu pemicu yang menyebabkan inefisiensi ketentuan yuridis nafkah anak adalah sikap para hakim yang berpegang pada pandangan ulama' fiqh yang menganggap bahwa nafkah anak tidak menjadi hutang ayah dan gugur setelah masa yang telah lampau. Sebagai contoh, putusan Mahkamah Agung R.I No.608 K/AG/2003 tanggal 23 Maret 2005 "menolak" gugatan nafkah anak yang sudah lampau atau lebih dikenal dengan sebutan nafkah madi yyah (Muchtar, 2014: 127; Rusyadi dan Hafifi, 2015: 472), dalam putusan MA tersebut berbunyi: “Ayah berkewajiban menafkahi anaknya secara lil intifa' tidaklah li tamlik, oleh kareanya jika terjadi kelalaian bagi ayah untuk menafkahinya, maka hal tersebut tidak dibenarkan untuk digugat" (Putusan MA RI No.608 K/AG/2003, 867-885).

Berdasarkan prolog di atas, maka penulis mengambil focus pembahasan mengenai bagaimanakah ketentuan hukum kewajiban nafkah anak menurut UUP Islam Indonesia dan nilai filosofisnya?.

\section{B. Metode}

Penelitian ini adalah menggunakan pendekatan ranah kualitatif. Penelitian ini sifatnya lebih ke arah metode kajian atas gagasan konseptual dengan data-data yang dikumpulkan dan yang akan dianalisis bertumpu pada ketersediaan sumber data di perpustakaan (Library Research). Sedang untuk teknik nalisis data yang digunkan dalam kajian ini adalah teknik Analisis isi (content analysis) memahami inti dari keterangan, pesan atau informasi yang disajikan dalam wujud lambang atau simbol tertentu yang terdokumentasi atau dapat didokumentasikan.

\section{Hasil dan Pembahasan}

\section{Nafkah Anak dalam Perkawinan menurut UUP Islam Indonesia}

Suami dan istri dalam hukum memiliki kedudukan yang sama, yaitu berhak membuat dan melakukan perbuatan hukum, baik istri sebagai ibu rumah tangga maupun suami sebagai kepala keluarga. Walaupun keduanya sama-sama memiliki hak dan kewajiban yang harus di penuhi antara yang satu dengan yang lainya. Sehigga keduanya jika melakukan kelalian dalam memenuhi kewajibanya, maka salah satu keduanya memiliki hak untuk menggugat yang lainya di pengadilan (Sudarsosno, 2010: 55).

JAS: Volume 1 Nomor 1, 2019 
Kewajiban dalam memenuhi nafkah juga sama, baik nafah lahir maupun batin, baik istri atau anak. Karena itu salah satu inti yang mesti didapatkan dalam pernikahan, jika ada pelanggaran atau kelalaian dan ada pihak yang dirugikan diperbolehkan melakukan gugatan ke pengadilan yang mempunyai kewenangannya. Ini semuanya sudah diatur dalam UUP No. 1 th 1974 Bab VI berkaitan kewajiban dan hak suami dan istri juga Bab X berkaitan dengan kewajiban dan hak kedua orang tua terhadap anak-anaknya (Sudarsono, 2010: 59).

Hukum normative di Indonesia mengenai nafkah anak, baik dalam perkawinan atau setelah berpisah, sudah cukup melindungi hak anak. Pasal s4 ayat 1 UUP No. 1 th 1974, menyatakan: suami wajib melindungi isteri dan memberikan segala keperluan hidup berumah tangga sesuai dengan kemampuannya. Ini bermakna suami berkewajiban member nafkah buat keluarga yaitu istri dan anakanaknya.

Pada ayat 1 pasal 34 UUP No. 1 th 1974, baik nafkah isteri maupun anak diatnngung nafkahnya oleh suami atau ayah dari si anak. Dalam ayat 3 pasal 34 nya menyatakan bahwa jika suami atau istri melalaikan kewajibannya masingmasing, maka dapat mengajukan gugatan ke pengadilan (Sudarsosno, 2010: 55).

Pada ayat 1 dan 2 pasal 45 menyatakan: maka orang tua si anak berkewajiban memeliharanya, memberikan pendidikan dengan sebaiknya dan juga kedua ibu bapaknya berkewajiban dalam pasal ini sampai anak tersebut kawin atau menikah atau mandiri, meskipun kedua orang tunya sudah bercerai (Projokdokoro, 2012: 24).

Kemudian ketentuan memberikan nafkah kepada anak diperkuat dengan adanya Pasal 80 ayat (4) bagian b dan c, Kompilasi Hukum Islam yang menyebutkan bahwa: "Sesuai dengan penghasilannya, suami menanggung: b). Biaya rumah tangga, biaya perawatan dan biaya pengobatan bagi anak isterinya; c). Biaya pendidikan bagi anak".

Menurut hukum perdata hak anak secara mutlak diatur dalam sistem hukum atau peraturan yang berlaku, baik timbul karena hak pribadi atau yang disebabkan karena adanya hukum dalam kekeluargaan (hukum keluarga Islam). Nafkah untuk anak tidak sekedar hak-hak individual melainkan hak kebendaan juga ada yang mesti ditunaikan seorang ayah kepada anaknya. Akibat dari hukum pernikahan diantaranya nafkah anak mesti dilaksanakan bagi seorang kepala rumah tangga (ayah). Maka jika itu tidak terlaksana dianggap perbuatan melawan hukum seorang ayah kepad hak anaknya, sehingga nafkah yang tertinggal dianggao hutang dalam hukum normative Indonesia (Mapiasse, 2015: 111-112). 
Pada pasal 47 UUP No. 1 th 1974 menjelaskan jika anak yang masih dibawah umur 18 tahun atau belum kawin, itu semuanya ada dalam penguasaan kedua orang tuanya sebelum cicabut atau dibebaskan hak penguasaannya, kemudian kedua orang tua sebagai wali dalam tindakan hukum di pengadilan (Umbara, 2011: 15).

Dalam hal penguasaan orang tua dapat dicabut, namun orang tua tidak dibebaskan kewajibannya membrikan nafkah anak. Hal ini telah diatur pada UUP th 1974 pasal 49: 1). Jika orang tua atau kedua orang tua si anak atas permintaan keluarga, saudara kandung atau pejabat yang berwenang dapat mencabut hak penguasaannya kepada anak pasa rentang waktu-waktu tertentu, jika terjadi, yaitu: a). Ia sangat melalaikan kewajiban terhadap anak. b). Ia memiliki akhlak yang jelek. 2). Kendatipun kedua orang tua telah diambil hak penguasaannya terhadap anak, namun kewajiban memberikan nafkah dan biaya dari pemeliharaan masih dibebankan kepadanya (Projodikoro, 2012: 55).

Pada ketentuan pasal 41 huruf b, maka dapat dimaknai pada dasarnya gugatan cerai dan gugatan tentang hak nafkah, kedua mempunyai ketentuan yang berbeda. Kedua kasus itu, maksudnya perceraian dan kewajiban nafkah anak di ajukan dalam gugatan yang berbeda. Karena menahan hak orang lain yang menjadi tanggungan merupakan kewajibannya, hal ini sudah menjadi urf dalam masyarakat, sama dengan dalam pernihakan (Sudarsono, 2010: 56).

Dicetuskannya tentang HAM anak oleh PBB secara sebenarnya tidak dapat dipandang secara otomatis dalam ketentuan hukum positif, oleh karenanya penguasa berkewajiban menetapkan Kepres, yaitu nomor 36 th 1990 tentang pengesahan Convention on The Right of The Child. Hal ini sduah dilakukan oleh pemerintah pada tahun 1979 dalam UU nomor 4 tentang kesejahteraan anak (Wijayanti, 2010: 21).

\section{Nafkah Anak Pasca Perceraian menurut UUP Islam Indonesia}

Pasca perceraian hak anak diatur dalam pasal 41 UUP th 1974, adanya perceraian antara kedua orang tuanya, maka suami atau ayah dari anak-anak tetap berkewajiban memberikan nafkah anak. Juga sudah dipertegas dalam Pasal 105 huruf (c) KHI, sesungguhnya dana dari biaya yang timbul dari pemeliharaan anak dibebankan kepada ayah si anak. Namun demikian dalam Pasal 41 huruf (b) Undang-Undang Perkwinan telah menjelaskan, jika ayah sianak kenyataannya belum bisa memenuhi hak anak tersebut, maka pengadilan bisa memtuskan bahwa ibunya ikut serta dalam mengeluarkan biaya tersebut. Kemudian untuk hak nafkah anak, pada huruf d pasla $149 \mathrm{KHI}$ sudah diterangkan, bila pernikahan sudah 
terputus disebabkan talak cerai, maka seorang mantan suami berkewajiban: d). Mengeluarkan biaya pemeliharaan atau pengasuhan (hadhonah) untuk anaknya yang masih belum dewasa yaitu belum berumur dua puluh satu tahun (Rahmanda, 2015: 5).

Hak anak setelah perceraian mendapatkan pemeliharaan, susuan (Hamid, 2010: 107), perawatan (KHI Pasal 105 huruf b dan c), pendidikan dan pembiayaan (Setiasari, 2008: 97). Pada Pasal 45 dinyatakan bahwa: 1). Orang tua mempunya kewajban memelihara dan memberikan pendidikan kepada anak dengan pendidikan yang baik. 2). Maksud dari ayat (1) hak ini berlaku hingga usia anak dewasa atau menikah atau mandiri, hal ini tetap berlaku kendatipun kedua orang tuanya sudah bercerai.

Hak anak kewajiban ayah memberikan nafkah dilegalkan dalam hukum normative Indonesia melalui UUP No. 1 th 1974 kemudian dikuatkan dengan KHI atau kompilasi hukum Islam. Apalagi dengan adanya UU perlidungan anak nomor 23 tahun 2002 dan UU nomor 4 th 1979 tentang kesejahteraan anak. UUP 1974 ayah berkewajiban memberikan nafkah anak walaupun kedua orang tuanya sudah bercerai (Rahmanda, 2015: 5).

Menurut Pasal 3 Undang-Undang Nomor 23 Tahun 2002 tentang Perlindungan Anak menyatakan bahwa, "perlindungan anak bertujuan untuk menjamin terpenuhinya hak-hak anak agar dapat hidup, tumbuh, berkembang, dan berpartisipasi secara optimal sesuai dengan harkat dan martabat kemanusiaan, serta mendapat perlindungan dari kekerasan dan diskriminasi, demi terwujudnya anak Indonesia yang berkualitas, berakhlak mulia dan sejahtera" (Thalib, 2014: 33).

Perlindungan anak adalah suatu usaha melindungi anak agar dapat melaksanakan hak dan kewajibannya. HAM anak ada dua, yaitu hukum yang formal (tertulis) dan non formal (tidak tertulis) semuanya menyatakan bahwa kedua orang tua menjamin anak-anaknya sampai anaknya mampu melaksanakan kewajiabnya sebagai anak. UU No. 4 th 1979 pasal 2 tentang kemakmuran anak menyebutkan hak anak adalah: Kesejahteraan, paerawatan asuhan dan bimbingan berdasarkan cinta kasih dan sayang, baik dalam keluarga atau di tempat pengasuhan khusus agar tercapai hak anak dalam mengembangkan kepribadiannya secara wajar (Husein, 2012: 44).

HAM anak sebelum terjadi perceraian atau putusnya perkawinan dikarenakan dalam kasus anak tidak ada istilah hukum mantan anak, melainya anak selamanya, jadi hak-haknya tetap ada kepada kedua orang tuanya meskipun kedua telah berpisah atau cerai (Jauhari, 2011: 12). 
Bab III UU HAM anak yang menentukan tentang kewajiban dan hak anak. Disini hak anak diatur secara jelas dalam pasal 4 sampai 18, sedangkan kewajiban anak dituangkan dalam pasal 19 Bab III UU tersebut. Hak anak dalam UU perlindungan anak adalah:

1) Agar hidup dengan layak, tumbuh berkembang dan berpartisipasi sesuai harkat dan martabat manusia dan mendapatkan hak dilindungi dari segala bentuk kekerasan serta diskriminasi.

2) Ada nama sebagai bentuk identitas diri sebagai warga negaraan.

3) Dapat menjalankan ibadaahnya sesuai ajaran agama, bernalar dan berinovasi disesuaikan dengan tingkat kepandaian dan usia selalu ada bimbingan orang tuanya.

4) Dapat mengenal siapa kedua orang tuanya, ditumbuh kembangkan serta dipelihara oleh keduanya.

5) Mendapatkan perawatan kesehatan juga jaminan sosial sesuai kebutuhannya, baik mental spritual dan sosial.

6) Mendapatkan pendidikan dan pengajaran dalam rangka pengembangan pribadi sesuai tinggi rendahnya kecerdasan, sesuai minat dan skilnya.

7) Mendapatkan dan memperoleh pendidikan yang luar biasa (PLS) atau SLB (sekolah luar biasa), rehabilitasi, bantuan sosial dan pemeliharaan taraf kesejahteraan sosial bagi yang cacat fisik.

8) Mendapatkan pendidikan yang lebih khusus bagi anak-anak yang memiliki kemampuan yang tinggi dan luar biasa.

9) Mendapatkan pernyataan yang bisa didengar dan dipertimbangkan pendapatnya, menerima, mencari dan memberikan informasi sesuai tingkat kecerdasan serta usianya demi pengembangan diri pribadi dalam koridor nilai-nilai kesusilaan dan kepatutan.

10)Dapat beristrahat dan memanfaatkan waktu luang, begaul, bermain, berrekreasi dan berinovasi sesuai skill, dan intelektual dan tingkat kecerdasan demi pertumbuhan diri anak.

11)Mendapatkan pengamanan dari perbuatan diskriminasi, eksploitasi, baik ekonomi maupun seksual, penelantaran, kekejaman, kekerasan, penganiayaan, ketidakadilan serta prilaku buruk lainya.

12)Mendapatkan pengasuhan dari kedua ayah ibunya, terkecuali jika ada alasan atau aturan hukum lainya demi kepentingan terbaik bagi anak-anak sebagai alternative terahir.

13)Mendapatkan perlindungan dari segala bentuk penganiayaan, penyiksaan atau kejahatan hukum lainya yang tidak berprikemanusiaan.

JAS: Volume 1 Nomor 1, 2019 
14)Mendapatkan hak berkebebasan menurut aturan hukum yang ada.

15)Mendapatkan perlakuan secara berprikemanusiaan dan tempat yang terpisah dari orang-orang yang sudah dewasa, mendapatkan perbuatan bantuan hukum dan bantuan lainya secara efektif sesuai tahapan upaya hukum yang ada, serta mendapatkan pembelaan diri dan mendapatkan keadilan didepan pengadilan anak secara objektif serta tidak memihak-mihak, dan sidang tertutup untuk umum pada siding kasus anak yang dirampas kebebasannya.

16)Dapat kerahasiaan setiap anak-anak yang telah menjadi korban kekerasan dan pelecehan seksual atau berhadapan dengan hukum lainya.

17)Mendapatkan pendampingan bantuan hukum dan bantuan lainya untuk anak yang telah menjadi korban atau pelaku tindak pidana anak.

Menurut perspektif perundang-undangan di Indonesia, kewajiban nafkah anak lebih diprioritaskan bagi seorang ayah, namun apabila ayah pada kenyataannya tidak mampu, maka ibu ikut memikul biaya tersebut. Anak yang sah dalam pernikhanlah sebenarnya yang memiliki hak untuk memperoleh nafkah dari ayahnya, sedangkan hasil dari perzinahan atau anak haram tidak ada hak untuk dinafkahi dalam pandangan hukum. Maka besarnya biaya nafkah disesuaikan dengan kemampuan sang ayah. Yang wajib diberikan kepada anak adakah biaya rumah tangga, perawatan, pengobatan dan pendidikan. Batasan usia dari maulai usia 0 sampai 21 tahun atau belum menikah, baik kedua orang tuanya masih dalam pernikahan ataupun tidak, sekalipun anak tersebut memiliki cacat badan atau jasad. Namun untuk aparatur sipil Negara (ASN) nafkah anak sesuai gaji si ayahnya jika telah cerai minimal sepertiga dari gaji ayahnya (Azizi, 2016: 226).

Hukum yang mengatur tentang kelalaian ayah dalam menafkahi anak-anaknya, maka bagi ayah di jegal dengan delik perdata dan pidana. Sanksi perdatanya digolongkan menjadi tiga macam, yaitu: a) seseorang dapat digugat ke pengadilan untuk mengganti biaya nafkah anak yang tidak diberikan kepada anak, sebagaimana tercantum pada pasal 34 ayat 3 UU Perkawinan No 1/1974 (Azizi, 2016: 226).

Di dalam hukum positif hak nafkah anak tetap berlaku pada jangka waktu yang telah lampau, sebab kewajiban untuk menunaikan kewajiban menafkahi anaknya dari mualai umur 0 tahun sampai umur kurang lebih 21 tahun (dua puluh satu tahun), selama dalam jangka usia tersebut, nafkah anak yang tidak dibayarkan pada masa lampau masih dapat dituntut, asalkan seorang ayah memang memiliki kecukupan harta dan ia enggan memberikannya, tetapi jika seorang ayah dalam keadaan miskin, sakit atau sulit mendapat pekerjaan maka ibu turut memikul biaya beban nafkah kepada anaknya; b) seseorang dapat dicabut hak kuasa asuh terhadap anaknya sebab melalaikan kewajibannya menunaikan nafkah anak, sebagaimana tercantum dalam pasal 49 ayat 2 UU Perkawinan dan Undang- undang No. 4/1979 tentang JAS: Volume 1 Nomor 1, 2019 
Kesejahteraan Anak; c) bagi PNS yang tidak mau melaksanakan ketentuan pembagian gaji apabila terjadi perceraian, dengan di sanksi diantara hukuman kedisisplinan yang tunggi sesuai dengan PP No. 30 th 1980. Sedangkan hukuman dalam delik tindak pidana jika seorang ayah melalikan tanggung jawab nafkah anak dipidana hukuman penjara lima tahun paling alama dan denda Rp: 100.000 .000 (seratus juta rupiah) sebagaimana tercantum di dalam UU No. 35 tahun 2014 huruf b pasal 77, atau pidana kurungan penjara 3 tahun paling lama atau denda Rp: 15.000.000 (lima belas juta) paling banyak, sebagaimana tercantum pada pasal 49 UU Nomor 23 Tahun 2004 (Azizi, 2016: 227).

\section{Makna Filosofis Aturan Nafkah Anak dalam UUP Islam Indonesia}

Nilai-nilai filosofi yang terkandung pada aturan nafkah anak UUP Islam adalah sebagai berikut (Azizi, 2016: 228):

1) Ditinjau dari aspek aksiologi kemanfaatan hukum, nafkah kepada anak merupakan medium untuk mencapai kesejahteraan masyarakat, dengan terpenuhinya nafkah anak berarti telah mempersiapkan sumber daya manusia yang berkualitas di masa depan, sebab di dalam nafkah anak terkandung tiga aspek pemenuhan kebutuhan dasar (basic need) anak. Pertama, pemenuhan kebutuhan jasmani anak yang mencakup kebutuhan pokoknya seperti makanan yang bergizi, pakaian dan tempat tinggal yang bersih, serta biaya perawatan anak sejak dalam kandungan sehingga anak kelak dapat tumbuh sehat secara fisik Kedua, pemenuhan kebutuhan rohani (psikis) anak, sebab anak yang mendapat nafkah secara rutin akan terjalin komunikasi yang baik dengan orang tuanya, dari situ ia akan merasakan kasih sayang dan perhatian orang tua. Ketiga, pemenuhan kebutuhan intelektual anak, sebab dengan mencukupi kebutuhan pendidikan anak baik dengan ilmu agama dan ilmu pengetahuan umum lainnya, anak-anak diharapkan siap dalam menghadapi iklim persaingan global di dunia pekerjaan (Azizi, 2016: 228).

2) Dari aspek aksiologi keadilan hukum, kewajiban menafkahi anak memiliki nilai teologis kedailan, sosial dan gender. Pertama, nilai keadilan teologis bermakna keadilan Ilahiah, jadi seseorang yang telah memenuhi nafkah kepada anaknya berarti ia telah berbuat adil karena telah patuh menjalankan perintah Allah, begitu pula sebaliknya seseorang yang tidak menjalankan kewajiban nafkah kepada anaknya berarti ia telah berbuat tidak adil karena tidak patuh menjalankan perintah Allah. Kedua, nilai keadilan sosial menekankan prinsip tolong-menolong dan persamaan (equality), prinsip tersebut dirumuskan dalam aturan pemberian nafkah kepada anak angkat dan nafkah bagi anak yang lahir di luar ikatan

JAS: Volume 1 Nomor 1, 2019 
perkawinan yang sah. Ketiga, nilai keadilan gender terkandung dalam pembebanan kewajiban yang setara antara suami-istri dalam hal memberi nafkah, merawat, dan membesarkan anak. Ketiga nilai keadilan tersebut penting diaplikasikan di masyarakat untuk membangun kontrak sosial yang berlandaskan moral agama, membantu anak-anak yang hidup dalam kesulitan sosial, dan membangun prinsip kesetaraan dalam keluarga (Azizi, 2016: 229).

Dari ranah aksiologi kepastian hukum, adanya sanksi hukum pada aturan perundang-undangan hukum keluarga di Indonesia berfungsi sebagai kontrol sosial sebagai upaya preventif untuk mencegah terjadinya tindak pengabaian nafkah anak, sekaligus sebagai upaya represif (memaksa) agar jika terjadi pengabaian nafkah anak orang tua dapat mengembalikan hak nafkah anak dengan membayarnya di kemudian hari, dengan upaya-upaya tersebut berarti negara telah menegakkan prinsip Islam yang menjamin adanya hak nafkah anak (Azizi, 2016: 229)

\section{Kesimpulan}

Berdasarkan pembahasan di atas, maka dapat disimpulkan, bahwa menurut perspektif perundang-undangan di Indonesia, kewajiban nafkah anak lebih diprioritaskan bagi seorang ayah, namun apabila ayah pada kenyataannya tidak mampu, maka ibu ikut memikul biaya tersebut. Besarnya nafkah yang wajib diberiakan sesuai kemapuan ayah, yaitu meliputi biaya rumah tangga, paerawatan, pengobatan dan pendidikan dari mulai umur 0 sampai 21 tahun atau sebelum menikah, kecuali ada cacat fiaik. Khusus bagi PNS nafkah anak 1/3 dari gaji sang ayah.

Nilai-nilai filosofi yang terkandung pada aturan nafkah anak UUP Islam adalah sebagai berikut:

1) Ditinjau dari aspek aksiologi kemanfaatan hukum, nafkah kepada anak merupakan medium untuk mencapai kesejahteraan masyarakat, dengan terpenuhinya nafkah anak berarti telah menciptakan calon intelektual manusia (SDA) yang berkopetensi tinggi di persaingan yang akan datang, tiga aspek pemenuhan dasar dari kebutuhan anak. Pertama, pemenuhan kebutuhan jasmani. Kedua, pemenuhan kebutuhan rohani (psikis) anak. Ketiga, pemenuhan kebutuhan intelektual anak.

2) Dari aspek aksiologi keadilan hukum, kewajiban menafkahi anak memiliki nilai teologis kedailan, sosial dan gender. Pertama, nilai keadilan teologis bermakna keadilan Ilahiah. Kedua, nilai keadilan sosial menekankan prinsip tolongmenolong dan persamaan (equality). Ketiga, nilai keadilan gender terkandung dalam pembebanan kewajiban yang setara antara suami-istri dalam hal memberi nafkah. 
Dari ranah aksiologi kepastian hukum, adanya sanksi hukum pada aturan perundang-undangan hukum keluarga di Indonesia berfungsi sebagai kontrol sosial sebagai upaya preventif untuk mencegah terjadinya tindak pengabaian nafkah anak, sekaligus sebagai upaya represif (memaksa) agar jika terjadi pengabaian nafkah anak.

\section{Daftar Rujukan}

Al-Subki, Ali Yusuf, Fiqih Keluarga: Pedoman Berkeluarga dalam Islam, (Jakarta: Amzah, 2011).

Azizi, Alfian Qodri, Jaminan Hak Nafkah Anak dalam Hukum Keluarga Islam di Indonesia, (Program Pasca Sarjana UIN Sunan Kalijaga, 2016).

Departemen Agama RI, Bahan Penyuluhan Hukum UUP No. 1 th 1974, (Jakarta: Derektorat Jenderal Pembinaan Kelembagaan Islam, 2011).

Departemen Agama RI, Kompilasi Hukum Islam di Indonesia, (Jakarta: Direktorat Jenderal Pembinaan Kelembagaan Islam, 1997/1998)Muchsin, "Perlindungan Hukum terhadap Anak Pasca Perceraian Orang Tuanya," Varia Peradilan: Majalah Hukum, (Ikatan Hakim Indonesia., No. 301, Tahun XXVI, Desember 2010).

Hamid, Zahri., Pokok-pokok Hukum Perkawinan Islam dan UUP di Indonesia, (Yogyakarta: Binacipta, 2010).

Husein, Abdul Rozak, Hak Anak dalam Islam, (Jakarta: fikahati Aneka, 2012).

Juahar, Imam., Perlindungan Hukum terhadap Anak dalam Keluarga Poligami, ( Medan:UsuPress, 2011).

Mappiasse, Achmad Habibul Alim, Hak Anak Atas Nafkah Terhutang Ayah dalam Perspektif Fiqh dan Hukum Positif (Studi Putusan MA No. 608 K/AG/2003), 9Yogyakarta : Jurusan Perbandingan Mazhab Fakultas Syari'ah Dan Hukum Universitas Islam Negeri Sunan Kalijaga, 2015).

Mas'ud, Muhammad Khalid, Filsafat Hukum Islam dan Perubahan Sosial, terj. Yudian W . Asmin, (Surabaya: al-Ikhlas, 2015).

Muchtar, Kamal., Asas-asas Hukum Islam tentang Perkawinan, (Jakarta: Bulan Bintang, 2014).

Nuruddin, Amir dan Tarigan, Azhari Akmal, Hukum Perdata Islam di Indonesia: Studi Kritis Perkembangan Hukum Islam dari Fiqih, UUP No. 1/1974 sampai KHI, (Jakarta: Kencana Prenada Media Group, 2016).

Projodikoro, Wirjono., Hukum Perkawinan Di Indonesia, (Bandung: Grafika, 2012).

Rahmanda, Agil Arya, Tinjauan Yuridis Terhadap Tanggung Jawab Orang Tua Terhadap Anak Setelah Perceraian (Studi Kasus di Pengadilan Agama Surakarta), (Fakultas Hukum Universitas Muhammadiyah Surakarta. 2015).

JAS: Volume 1 Nomor 1, 2019 
Filosofis Kewajiban Nafkah Anak Dalam UUP Islam Indonesia

Rusyadi dan Hafifi, Kamus Indonesia Arab, (Jakarta: Rineka Cipta: 2010).

Setiasari. Meta Deasiy, Kewajiban ayah kepada Anak setelah Putusnya Perkawinan karena Perceraian menurut Hukum Islam dan KHI, (Fakultas Hukum Universitas Indonesia Depok, 2008).

Sudarsono, Hukum Perkawinan Nasional, (Jakarta: Rineka Cipta, 2009).

Thalib, Yusuf., Pengaturan Hak Anak dalam Hukum Positif, (Jakarta: PBHN, 2014).

Wijayanti, Rina., Hak-hak Anak, (Jakarta: Sinar Pustaka, 2010).

JAS: Volume 1 Nomor 1, 2019 